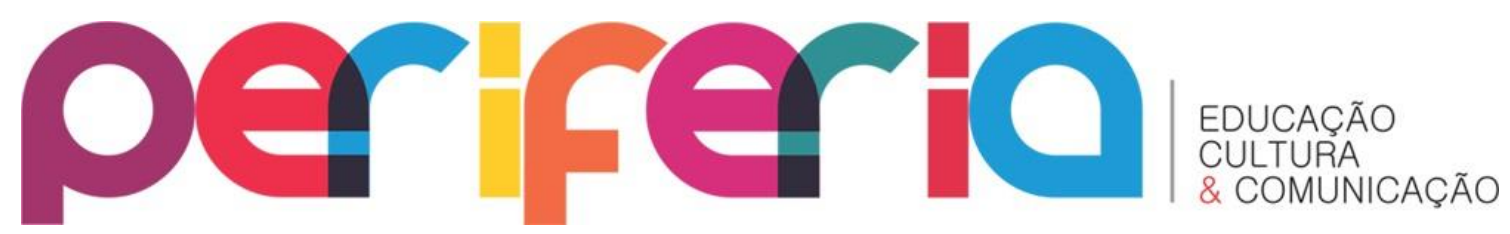

\title{
SHARING THE SPIRIT, FANNING THE FLAMES OF SOCIAL JUSTICE
}

\author{
Rosangela Malachias ${ }^{1}$ \\ Universidade do Estado do Rio de Janeiro - UERJ \\ Elizabeth C. Reilly ${ }^{2}$ \\ Loyola Marymount University \\ Kay Fuller ${ }^{3}$ \\ University of Nottingham
}

From its first conference held in Rome in 2007, when members of Women Leading Education (WLE) began profiling the progress, successes, and challenges of women leaders internationally and offering theories to expand our understanding of women in leadership, we have had the opportunity not only to meet together at our bi-yearly conferences as scholars and practitioners face-to-face, but to extend our work beyond them. Numerous research initiatives, conference presentations, and publications have resulted from the collaboration of WLE colleagues.

In all of our work, the messages address deeds, dreams, suffering, and triumph. Our research and calls to action reflect two principal themes. First, they ask us to be mindful of the moral imperative of women's leadership in addressing the most critical issues our global society faces - issues of access to the basic rights of all human beings: to freedom, to justice, and to equity.

\footnotetext{
1 Doutora em Ciências da Comunicação pela ECA-USP Escola de Comunicações Artes da Universidade de São Paulo, com bolsa do Fundo Rioychi Sasakawa (Japão).É Professora Adjunta da UERJ-FEBF - Universidade do Estado do Rio de Janeiro - Faculdade de Educação da Baixada Fluminense no Departamento de Ciências e Fundamentos da Educação. É membro do grupo WLE desde 2007, na $1^{\text {a }}$ conferência em Roma. rosmalach@gmail.com

$2 \mathrm{PhD}$ in Education - Ed.D -Organization and Leadership at University of San Francisco. MA Teaching and Curriculum and Urban Leaders Instructions; BA English and Communication Arts both at University of the Pacific. Professor \& Department Chair of Educational Leadership at School of Education - Loyola Marymount University. Los Angeles, California. Member of WLE Group since the First Conference in Rome, 2007. elizabeth.reilly@lmu.edu

$3 \mathrm{PhD}$ focused on Gender and Secondary School Leadership. She is Associate Professor of Educational Leadership at University of Nottingham. Prior to that she was Lecturer in Education, and course leader of the secondary English PGDipEd at the University of Birmingham (2007-2014). Kay is Member of WLE Group since the First Conference in Rome, 2007. kay.fuller@nottingham.ac.uk
}

Periferia, v. 10, n. 2, p. 13-20, jul./dez. 2018

DOI: 10.12957/periferia.2018.35860 


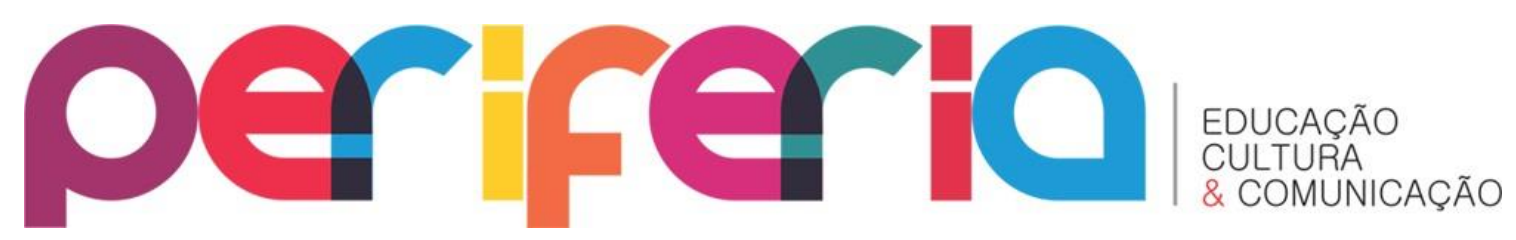

Second, they ask us to recognize that by taking action, we fulfill the responsibilities entrusted to us.

Each time we have met together, we have committed to a publication based on the work presented. Each conference draws internationallyrecognized scholars and practitioners who offer a research-based conversation and systematic collaborative inquiry in exploring the status of women in educational leadership. Our work invites global policy development highlighting women's educational leadership as a critical social justice issue. Thus, either a book or journal was the scholarly product of all conferences. It was in this spirit, then, that this journal - Revista Periferia - from Universidade do Estado do Rio de Janeiro - Faculdade de Educação da Baixada Fluminense (Rio de Janeiro State University - School of Education from Baixada Fluminense / UERJ-FEBF) came to be and the first bilingual collection and publication from WLE.

LYMAN, L. \& Strachan, J.. Shaping social justice leadership: Insights of women educators worldwide. Lanham, MD: Rowman \& Littlefield Education, 2012.

MCNAE, R. \& Reilly, E. C. (Eds.) Women leading education across the continents: Finding and harnessing the joy in leadership. Lanham, MD: Rowman \& Littlefield Education, 2018.

REILLY, E. C. \& BAUER, Q. (Eds.) Women leading education across the continents: Overcoming the barriers. Lanham, MD: Rowman \& Littlefield Education, 2015.

SOBEHART, H. C. (Ed.). Women leading education across the continents: Sharing the spirit, fanning the flame. Lanham, MD: Rowman \& Littlefield Education, 2009.

The online journal - Revista Periferia (UERJ-FEBF) - defines the concept of Periphery "not only as a geographical location of certain regions and the social and economic aspects", but designates it as "the social phenomena and the cultural manifestations, innovative or alternative character pointing to new scenarios, new modes of appropriation and cultural production" (REVISTA PERIFERIA).

According the IPAHB - Instituto de Pesquisa e Análises Históricas da Baixada Fluminense (Historical Research and Analysis Institute of Baixada 


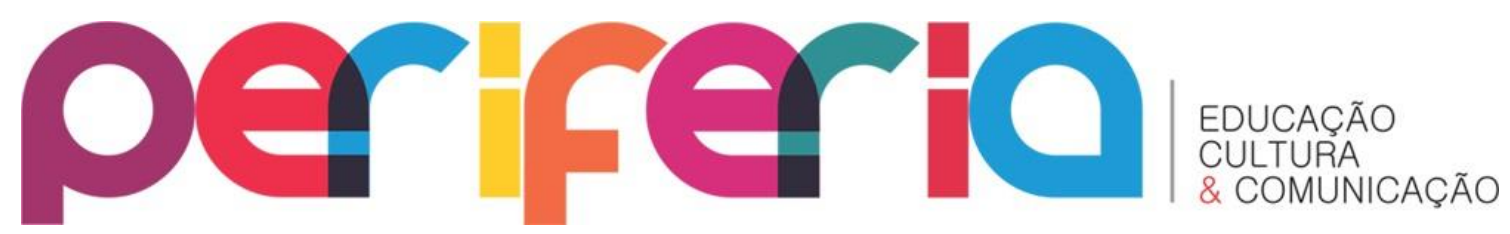

Fluminense) the region - Baixada Fluminense, BF - is located between the coast of the state of Rio de Janeiro and Serra do Mar. It is formed by a relief of low plains covering only the municipalities located north of the city of Rio de Janeiro. The BF' inner conurbations are: Belford Roxo, Duque de Caxias (where the FEBF, one from seven UERJ campuses is placed), Guapimirim, Itaguaí, Japeri, Magé, Mesquita, Nilópolis, Nova Iguaçu, Paracambi, Queimados, São João de Meriti, and Seropédica. Some decades ago, this region was known as the Guanabara Bay - in southeastern Brazil. Since the seventies, during the military dictatorship (1964-1985), BF came to mean the fusion between the geographic, social and cultural contexts. Their dormitory towns recorded high levels of violence, more precisely murders, explained by the absence of public policies (IPAHB, 2007) and political will of the different governmental bodies.

Simultaneously and paradoxically, local and social movements have been working in order to develop practices and speeches against the violence and stereotypes persistently directed to this region. These actions occur mainly in the spheres of culture, as music and cinema; education and community building for the defense of rights. The BF also became a region in which collective participation as peripheral resistance in culture has been developing. It is the Periphery showing its subjectivities and intersections from margins to centers.

In this special edition, Revista Periferia - Online Journal - brings together some authors who presented their research at 6th Women Leading Education Conference - From Margins to Centers, in Duque de Caxias, RJ, Brazil - July 23$292017^{4}$. The event celebrated 10 years of the WLE international group of Women from different countries and continents who, since 2007, have studied and worked for the implementation of social justice in the leadership of educational institutions, non-governmental organizations and in wider society.

The WLE network is growing despite of or perharps because of, the loss of rights across the world. According to a UN Report (2016) gender inequalities are maintained and enhanced including in academic careers. Universities need to promote equality between men and women, however the adoption of social

\footnotetext{
${ }^{4}$ This scientific event was sponsored by CAPES/PAEP.

Periferia, v. 10, n. 2, p. 13-20, jul./dez. 2018

DOI: 10.12957/periferia.2018.35860
} 


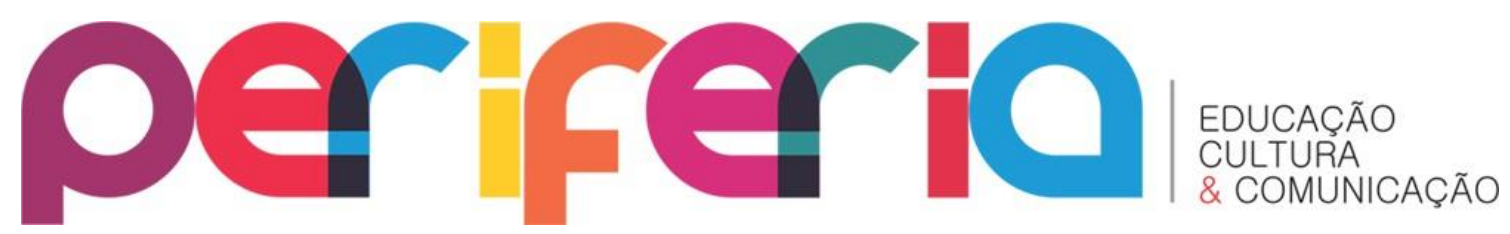

justice is not an easy task in a historical and cultural context, in which stereotypes of gender act as beliefs justification for the subordination of women.

Basic and higher education must contribute to the understanding of the human rights and to the eradication of violence. Brazil registers a high number of crimes against women known as the 'femicide' crime (murder of woman because of their gender). According to data broadcast by the States Prosecutors, at least eight cases of femicide occured in the country per day between March 2016 and March 2017. In total, there were 2925 cases of femicide crime; an $8.8 \%$ increase compared to the previous year (Ministério Público, 2017).

UERJ - Rio de Janeiro State University - one of the best higher education institutions in the country - is not free from the economic repercussions. It has been subjected to financial cuts that directly affected the payment of faculty members' salaries and the payment of scholarships to students. This governmental policy directly harms the access and retention of students from the less privileged classes; and compromises the quality of the research and extension projects of the university, that has a tradition of being a much revered public institution.

\#UERJResiste! became a slogan and symbol of the struggle in defense and resistance of public education. The first half of 2017 was probably the hardest period for the students, technicians and faculty who study - work and teach at UERJ. Two years before, in 2015, Brazil had been chosen to host the 6th WLE Conference. The election was made in University of Waikato, Hamilton, New Zealand during the 5th WLE Conference.

In May 2016, by an email election the slogan "From Margins to Centers" was chosen as the main topic for the meeting scheduled for July 2017 in the FEBF campus, Duque de Caxias, BF. Because of the absence of payment of salaries and respecting the workers' strike on campus, the local coordinator ${ }^{5}$, who is professor at UERJ-FEBF, in partnership with the Department of Culture

${ }^{5}$ Dr. Rosangela Malachias.

Periferia, v. 10, n. 2, p. 13-20, jul./dez. 2018 


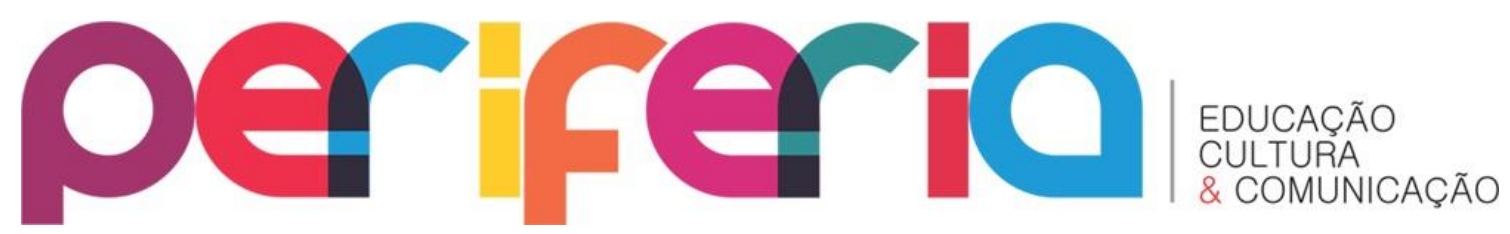

from Duque de Caxias city arranged to accommodate the conference in the Leonel de Moura Brizola municipal Library and in classrooms at SESI School, both places in downtown Duque de Caxias.

Building and sustaining a research-focus and social network with a serious commitment to the social justice agenda is not easy work. However during the 10 years, from July 2007, the WLE - Women Leading Education group of scholars has grown in the world and this growth is not just measured as the numbers of members, but it can also be measured by the enhancement of issues about social justice related to women.

The growth includes members, from all the continents, understanding about the relevance of the status of women and girls in the education systems and society. Bringing together scholars from different continents for the 6th WLE Conference at BF - Baixada Fluminense - was a choice for the Margins perspective. Periphery instead a center. This choice was reflected in the Program and topics: Leadership and Gender; Leadership and Human Rights; Ethnicity; Traditional Population; Formal and Non Formal Education.

Among 94 participants, 55 papers were presented by researchers from 12 countries $^{6}$. This edition of Revista Periferia reflects only a small group of people and their knowledge. In the Brazilian articles readers can learn about the relationship between oralcy and writing in the indigenous school Guarani Mbya, in Rio de Janeiro. The authors report on education from the female perspective of a Guarani teacher who has been working for more than ten years in the school focused on her people.

Two articles focus on Mato Grosso state. One, is about a black teacher who works in a primary school in the Vale do Arinos region, MT, who became an essential reference to other educators because of methodologies that were developed by her to the implementation of Federal Law 10.639/03. This legislation refers to the teaching of Afro-Brazilian and African Culture and History. The other article approaches the patriarchy role in the lives of women from traditional population living in rural areas at Mato Grosso state. They were

\footnotetext{
${ }^{6}$ Australia, Brazil, Ghana, England, India, Kenya, New Zealand, Nigeria, Pakistan, Philippines, Uganda, United States.
}

Periferia, v. 10, n. 2, p. 13-20, jul./dez. 2018

DOI: $10.12957 /$ periferia.2018.35860 


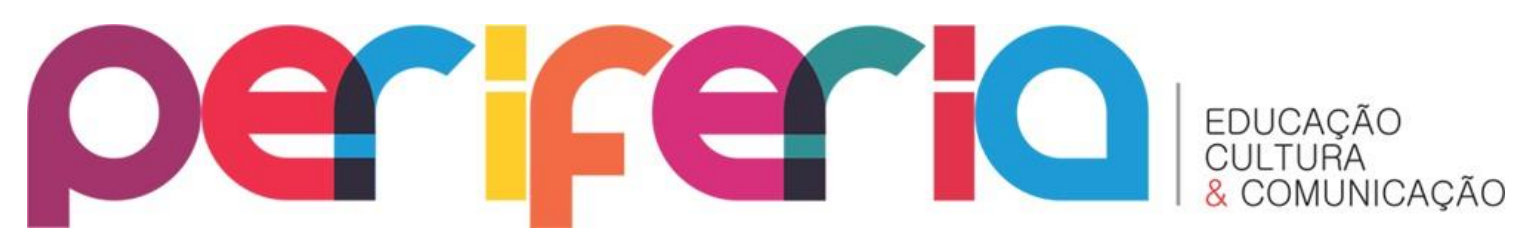

subject and protagonists of the study and practices made by the Center of Territorial Development of Baixada Cuiabana from University of the State of Mato Grosso. The article exposes how committees of Quilombolas ${ }^{7}$ women and of Youth were created to face and change disparities of gender. [In the past Quilombos were a fortified settlement of blacks escaped from slavery, endowed with divisions and internal organization. After abolition the inhabitants of these lands came to be identified as the Quilombolas].

In 1882, six years before the Slavery Abolition in Brazil (1888), a Catholic college for girls called Educandário Nossa Senhora da Piedade was built in Paraíba do Sul city, Rio de Janeiro State obeying the Mariana Claudina Pereira de Carvalho testament. The Countess of Rio Novo as she was known and the Educandário history are topics of interest from a period in which women did not access formal education.

The gender portrayal in education materials can reproduce and perpetuate stereotypes. This statement is among other conclusions from the article about a specific book - Tosco - which is widely used in Brazilian public schools as teaching material supporting drug prevention. The narrative describes female characters in stereotypical ways and despite the relevance that drug prevention has, in other ways, the book reinforces gender inequalities.

Gender inequalities also appears in the representation of women in politics. The article shows a historical line of women's presence in the politics of the city of Duque de Caxias from Baixada Fluminense, RJ. Authors say the fact that a woman was a protagonist in the political environment occupying position of responsibility and power, emphasizes the constraints and incompatibilities that persist in female representations in Brazilian society.

The last Brazilian text is a double interview with two black women leaders in culture and education issues in Ribeirão Preto, SP, city known as "the Brazilian California". 75 years old, social activism in the Women's

\footnotetext{
7 In the past Quilombos were a fortified settlement of blacks escaped from slavery, endowed with divisions and internal organization. After abolition the inhabitants of these lands came to be identified as the Quilombolas.
} 


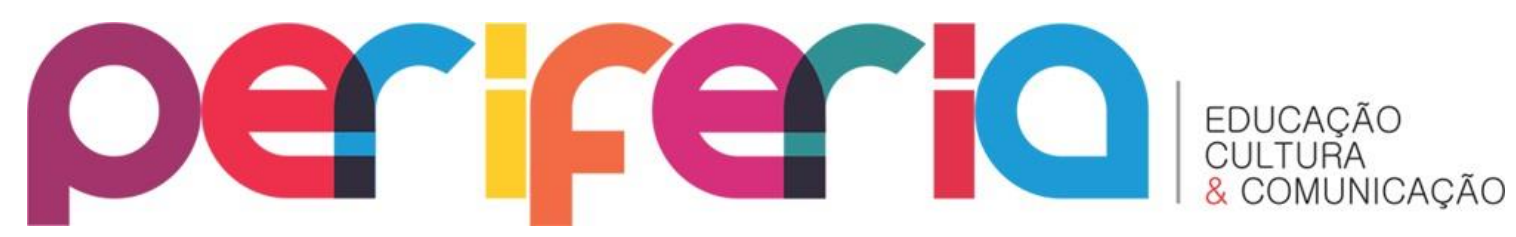

Movement and the Black Movement unifies their histories. Both belongs to Casa da Mulher / Woman' House, a non-governmental organization that has been working for girls' and women's empowerment. The poetry is their contemporary "gun" used at a local (and global) event, the Sarau Preto.

The English language contributions to this special issue include work that focuses on the experience of Black women in educational leadership, women's mentoring practices, and an account of the experience of disabled children in education in India. These articles focus on the work of Women Leading Education in a number of ways. First, the autoethnographic study of four Black women ensures that the voices of Black women are heard loud and clear. Contextualizing the work in an account of the United States legacy of slavery is a powerful reminder of the impact of historical and social contexts in the work of educationists. This example of researchers speaking in our own voices resonates with the publication of Shaping Social Justice Leadership (LYMAN, STRACHAN and LAZARIDOU, 2012). That book gives voice to women who have participated in WLE from across the continents. So too, the recommendation made at the end of the article resonate with the WLE network of scholars that emphasize community and collaboration.

The second article focuses on women's mentoring practices as it recounts the experience of women principals following a guide to mentoring novice principals for the first time. This article emphasizes the importance of relational leadership (GROGAN and SHAKESHAFT, 2011) ; $^{8}$ the sense of horizontal relationships that enable women to use power to empower rather than to control. The author recommends scholars look for examples of team mentorship to take the focus away from a dyadic model.

Third, the authors of the article focused on the education of disabled children in India remind us of the WLE focus on leadership for social justice. This article makes a welcome contribution to a limited literature about disability and education in India.

\footnotetext{
${ }^{8}$ GROGAN, Margaret; SHAKESHAFT, Charol. Women and Educational Leadership. San Francisco, CA: Jossey-Bass, 2011./ LYMAN, Linda, STRACHAN, Jane and LAZARIDOU, Angeliki. Shaping social justice leadership: Insights of women educators worldwide. Lanham, MA., Rowman and Littlefield with the American Association of School Administrators, 2012.
}

Periferia, v. 10, n. 2, p. 13-20, jul./dez. 2018

DOI: $10.12957 /$ periferia.2018.35860 


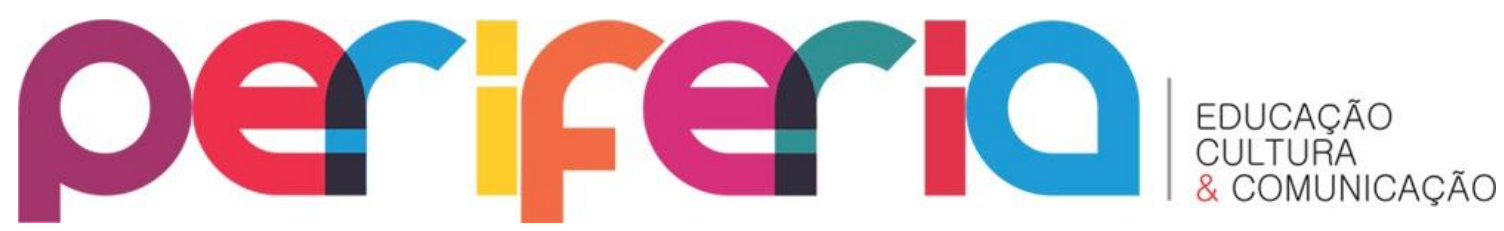

The fourth article begins with a brief overview of the meaning of leader resilience and describes the resilience cycle that all leaders experience when adversity strikes.

The last contribution is an interview with a Pakistani woman leader and the challenges about the gap on gender approaches in the global society.

The WLE quest continues as we build and expand our community and document the status of women leaders internationally. It is our hope that within these pages you find inspiration for the intellect and imagination for continuing the work of women in educational leadership across the continents. 